\title{
The Genetic Variations of SQSTM1 Gene are Associated with Bone Density in the Korean Population
}

Hyun-Seok Jin and Yong-Bin Eom*

Department of Medical Genetics, School of Medicine, Ajou University, Suwon 443-721, Korea

${ }^{1}$ Department of Biomedical Laboratory Science, Korea Nazarene University, Cheonan 331-718, Korea

Received September 7, 2010 /Accepted October 27, 2010

\begin{abstract}
Osteoporosis is a complex systemic skeletal disease and a major public health concern worldwide. It is a heritable disorder characterized mainly by low bone density and/or low trauma osteoporotic fractures, both of which have strong genetic determination. However, the specific genetic variants determining risk for low bone density are still largely unknown. Here, we performed association analysis to elucidate the possible relationship between genetic polymorphisms in the SQSTM1 gene and low bone density. By examining a total of 7225 (men: 3622, women: 3603) subjects from the Korean population in the Korean Association REsource (KARE) study, we discovered that SQSTM1 gene polymorphisms were associated with bone density. The results of the BD-RT (bone density estimated by T-score at distal radius) showed that three SNPs (rs513235, rs3734007, and rs11249661) within the SQSTM1 gene were significantly associated with bone density. The results of the BD-TT (bone density estimated by T-score at midshaft tibia) showed that four SNPs (rs513235, rs3734007, rs2241349, and rs11249661) were significantly associated with bone density. The three SNPs (rs513235, rs3734007, and rs11249661) had common significance in both BD-RT and BD-TT. In summary, we found statistically significant SNPs in the SQSTM1 gene that are associated with bone density traits. Therefore, our findings suggest SQSTM1 gene could be related to pathogenesis of osteoporosis.
\end{abstract}

Key words : Bone density, SQSTM1, SNP, association

\section{Introduction}

Bone density is a medical term referring to the amount of matter per square centimeter of bones, and used in clinical medicine as an indirect indicator of osteoporosis and fracture risk. Bone density measurements are used to screen women for osteoporosis risk and to identify those who might benefit from measures to improve bone strength [3].

The sequestosome-1 protein is encoded by the SQSTM1 gene, which is located in chromosome 5 q35 region and sequestosome- 1 binds ubiquitin and regulates activation of the nuclear factor kappa-B (NF-kB) signaling pathway $[7,13]$. Mutations in this gene result in sporadic and familial Paget disease of bone [6,8]. Paget disease of bone (PDB) is a common metabolic bone disease characterized by increased and disorganized bone turnover [11]. These abnormalities disrupt normal bone architecture and lead to various complications such as bone pain, bone deformity, deafness, nerve compression syndromes, pathological fracture and secondary osteoarthritis [12]. Genetic factors play an important

*Corresponding author

Tel : +82-41-570-4166, Fax : +82-41-570-4258

E-mail : omnibin@kornu.ac.kr role in PDB and mutations or polymorphisms have been identified in four genes that cause classical Paget's disease and related syndrome. These include TNFRSF11A, which encodes RANK, TNFRSF11B which encodes osteoprotegerin, $V C P$ which encodes p97, and SQSTM1 which encodes p62. All of these genes play a role in the RANK-NFkB signaling pathway and it is likely that the mutations predispose to PDB by disrupting normal signaling, leading to osteoclast activation [11], and underscoring the critical importance of this signaling pathway in bone metabolism and bone disease.

Despite of SQSTM1 is genetic factor causing PDB, there is rarely a report about association with SQSTM1 and bone density. In this study, we examined the association with genetic variations in SQSTM1 and bone density in the Korean population. Notably, this study provides insight into the relation with SQSTM1 and bone density.

\section{Materials and Methods}

\section{Subjects and clinical characteristics}

Subjects in the Korean population in the Korean Association REsource (KARE) study were described in more detail by other study [1]. Briefly 10,038 persons in the 
Ansung-Ansan prospective community cohorts were recruited. The initial numbers of subjects who were aged 40 to 69 years from Ansung and Ansan were 5018 and 5020, respectively. Of the 10,038 subjects, 1196 were excluded due to poor genotyping data. In addition, 1291 subjects who were on drug treatments that were also excluded.

It was investigated that 7225 subjects measured bone density among remaining subjects. Their basic characteristics-eg, bone density measures- are described in Table 1 . Bone density is a proxy measurement for bone strength, which is the resistance to fracture, widely used to screen for osteoporosis. Bone density was estimated by T-score by dividing the difference of measured SOS (speed of sound) from mean SOS in healthy young adult population by the standard deviation of SOS in young adult population. Bone SOS was measured quantitative ultrasound at distal radius or mid-shaft tibia in the subjects of the KARE study. This study was approved by the institutional review board of the Korean National Institute of Health (KNIH). Written informed consent was obtained from all subjects.

\section{Genotyping and selection of SNPs}

The detailed genotyping and quality control processes were reported in Cho et al. [1]. Briefly, most DNA samples were isolated from the peripheral blood of participants and genotyped using the Affymetrix Genome-Wide Human SNP array 5.0 (Affymetrix, Inc., Santa Clara, CA, USA). The accuracy of the genotyping was calculated by Bayesian Robust Linear Modeling using the Mahalanobis Distance (BRLMM) algorithm [10]. Samples that had genotyping accuracies were lower than $98 \%$, high missing genotype call rates $(\geq 4 \%)$, high heterozygosity $(>30 \%)$, or gender biases were excluded.

The SNPs that we analyzed were selected from the KARE data, based on their positions within the gene boundary (20 $\mathrm{kb}$ upstream and downstream of the first and last exons, respectively) (Table 2). The positions of the SNPs were validated in the NCBI database (http://www.ncbi.nlm.nih.gov). The clinical information and genotype data that we used were graciously provided by the Center for Genome Science, $\mathrm{KNIH}$, Korea Center for Disease Control (KCDC).

\section{Statistical analysis}

Most statistical analyses were performed using PLINK version 1.07 (http://pngu.mgh.harvard.edu/ purcell/plink) and PASW Statistics version 17.0 (SPSS Inc., Chicago, IL, USA). Linear regression was used to analyze BD-RT (bone density estimated by T-score at distal radius) and BD-TT (bone density estimated by $\mathrm{T}$-score at midshaft tibia) as quantitative traits in the final 7225 subjects, controlling for cohort, age, and sex as covariates.

All association tests were based on an additive, dominant, or recessive model, and $p$ values were not adjusted for multiple tests. Statistical significance was determined at a two-tailed value of $p<0.05$.

\section{Results}

Association analysis with SNPS in SQSTM1 gene and bone density

We informed the SQSTM1 gene and its SNPs (Table 2). And, the basic characteristics of study subjects were shown to Table 1 . The mean age of the 7225 study subjects was

Table 1. Basic characteristics of study subjects

\begin{tabular}{|c|c|c|c|c|}
\hline & $\begin{array}{c}\text { Total } \\
\text { Mean } \pm \text { SD (no.) }\end{array}$ & $\begin{array}{c}\text { Men } \\
\text { Mean } \pm \text { SD (no.) }\end{array}$ & $\begin{array}{c}\text { Women } \\
\text { Mean } \pm \text { SD (no.) }\end{array}$ & $p$ value* \\
\hline Age (yr) & $51.55 \pm 8.81(7225)$ & $51.29 \pm 8.70(3622)$ & $51.80 \pm 8.91(3603)$ & 0.014 \\
\hline \multicolumn{5}{|l|}{ Bone density } \\
\hline Distal Radius T score & $0.18 \pm 1.39(7153)$ & $0.17 \pm 1.20(3606)$ & $0.18 \pm 1.56(3547)$ & 0.809 \\
\hline Midshaft Tibia $\mathrm{T}$ score & $-0.31 \pm 1.49(7187)$ & $0.25 \pm 1.16(3617)$ & $-0.89 \pm 1.56(3570)$ & $<0.0001$ \\
\hline
\end{tabular}

*Significant differences in phenotypes between men and women were compared using student's t-test

Table 2. Information of studied SNPs in SQSTM1 gene

\begin{tabular}{clcccc}
\hline No. & SNP & Position, bp & Minor allele & MAF & Function \\
\hline 1 & rs513235 & 179181705 & $\mathrm{~T}$ & 0.241 & Intron 1 \\
2 & rs3734007 & 179185143 & $\mathrm{~T}$ & 0.160 & Intron 5 \\
3 & $\mathrm{rs2241349}$ & 179192615 & $\mathrm{C}$ & 0.328 & Intron 5 \\
4 & $\mathrm{rs} 2303676$ & 179201681 & $\mathrm{~A}$ & 0.246 & Downstream \\
5 & $\mathrm{rs11249661}$ & 179210480 & $\mathrm{C}$ & 0.175 & Downstream \\
\hline
\end{tabular}


51.55 years, that of men $(n=3622)$ was 51.29 years, that of women $(n=3603)$ was 51.80 years. The mean BD-RT of the 7153 subjects was $0.18 \pm 1.39$, and the mean BD-TT of the 7187 subjects was $-0.31 \pm 1.49$ (Table 1 ). But, the mean and variance of BD-TT was statistically different between sex groups (men: $0.25 \pm 1.16$, women: $-0.89 \pm 1.56, p<0.0001$ ) by Student's T-test in Table 1.

Linear regression analysis was used to associate genotypes with bone density traits, controlling for age, sex, and cohort as covariates. The results of associations on the five SNPs of SQSTM1 gene in total, men, or women subjects were listed in Table 3.

The results on the BD-RT, three SNPs (rs513235, rs3734007, and rs11249661) were significantly associated with bone density in total or subjects divided by sex (Table 3). The SNP rs513235 had significance in men ( $\beta=0.080$, additive $p=0.013$, recessive $p=9.2 \times 10^{-4}$ ), and the SNP rs3734007 also had significance in men $(\beta=0.054$, recessive $p=0.014)$. The SNP rs11249661 was significantly associated in total $(\beta=0.038$, recessive $p=0.037$ ) and men $\left(\beta=0.066\right.$, recessive $\left.p=5.4 \times 10^{-3}\right)$

The results on the BD-TT, four SNPs (rs513235, rs3734007, rs2241349, and rs11249661) were significantly associated with bone density in total or subjects divided by sex (Table 3). The SNP rs513235 had significance in total ( $\beta=0.069$, additive $p=7.2 \times 10^{-3}$, dominant $p=0.026$, recessive $\left.p=0.024\right)$, and women $(\beta=0.085$, additive $p=0.025$, dominant $p=0.027)$. And the SNP rs3734007 had only significance in total $(\beta=0.077$, additive $p=0.010$, dominant $p=4.3 \times 10^{-3}$ ). The SNP rs2241349 was significantly associated in total $(\beta=0.062$, additive $p=8.3 \times 10^{-3}$, dominant $p=0.029$, recessive $\left.p=0.033\right)$ and men $(\beta$ $=0.062$, additive $p=0.030$, dominant $p=0.021$ ). And the last SNP rs11249661 was significantly associated only in total $(\beta$ $=0.081$, additive $p=4.9 \times 10^{-3}$, dominant $p=3.1 \times 10^{-3}$ ). The three SNPs (rs513235, rs3734007, and rs11249661) had commonly significance in both BD-RT and BD-TT.

Age-dependent associations with SNPS in SQSTM1 gene and bone density

The most important risk factors for osteoporosis are advanced age (in both men and women), caused by a rapid reduction of bone density is related with estrogen deficiency following menopause in women, and a drop in testosterone levels had a similar effect in men. Therefore, we divided the subjects grouped into three subgroups by age (40s-, 50s-, and 60s-aged group). And, genetic variations of the present study were reanalyzed in the age (Table 4).

Genetic variations of SQSTM1 in 40s-, and 60s-aged men were associated with BD-RT. But, three aged women were not at all associated with BD-RT. And all 50s-aged subjects had no association with both BD-RT and BD-TT. The highest significant SNP in BD-RT was rs513235 in 60s-aged men $(\beta$ $=0.196$, additive $p=8.7 \times 10^{-3}$, recessive $p=2.3 \times 10^{-4}$ ) (Table 4).

And the results show that there were significance in 40s-aged men, and 60s-aged women with BD-TT. The highest significant SNP in BD-TT was also rs513235 the same in BD-RT, and there was association in 60s-aged women $(\beta$

Table 3. The associations with genetic variations of SQSTM1 gene and bone density estimated by T-score, controlling for cohort, age, and sex

\begin{tabular}{|c|c|c|c|c|c|c|c|c|c|c|c|c|c|c|}
\hline \multirow[t]{2}{*}{ SNP } & \multirow{2}{*}{$\begin{array}{l}\text { Minor } \\
\text { allele }\end{array}$} & \multirow[t]{2}{*}{ MAF } & \multicolumn{4}{|c|}{ Total $(n=7225)$} & \multicolumn{4}{|c|}{ Men $(n=3622)$} & \multicolumn{4}{|c|}{ Women $(n=3547)$} \\
\hline & & & beta \pm s.e.m. & Add $p$ & Dom $p$ & $p \operatorname{Rec} F$ & & Add $P$ & Dom $p$ & $\operatorname{Rec} p$ & beta \pm s.e.m. & Add $p$ & Dom $p$ & $p \operatorname{Rec} p$ \\
\hline BD-RT & & & & & & & & & & & & & & \\
\hline rs $513235^{*}$ & $\mathrm{~T}$ & 0.241 & $0.036 \pm 0.03$ & 0.163 & 0.364 & 0.091 & $0.080 \pm 0.03$ & $\underline{0.013}$ & 0.143 & $9.2 \times 10^{4}$ & $-0.026 \pm 0.04$ & 0.486 & 0.655 & 0.387 \\
\hline rs3734007* & $\mathrm{T}$ & 0.160 & 0.036 & 0.222 & 0.334 & 0.223 & & 0.142 & 0.430 & $\underline{0.014}$ & \pm 0.04 & 92 & 0.981 & 0.310 \\
\hline rs2241349 & $\mathrm{C}$ & 0.328 & $0.021 \pm 0.02$ & 0.380 & 0.715 & 0.194 & $0.036 \pm 0.03$ & 0.222 & 0.236 & 0.469 & $0.002 \pm 0.03$ & 0.959 & 0.616 & 0.336 \\
\hline rs2303676 & A & 0.246 & $0.006 \pm 0.03$ & 0.809 & 0.679 & 0.813 & $-0.013 \pm 0.03$ & 0.683 & 0.770 & 0.097 & $0.023 \pm 0.04$ & 0.536 & 0.677 & 0.478 \\
\hline rs11249661* & C & 0.175 & $0.038 \pm 0.03$ & 0.183 & 0.440 & $\underline{0.037}$ & $0.066 \pm 0.04$ & 0.067 & 0.288 & $\underline{5.4 \times 10^{-3}}$ & $-0.024 \pm 0.04$ & 0.569 & 0.569 & 0.828 \\
\hline & & & & & & & & & & & & & & \\
\hline rs $513235^{*}$ & $\mathrm{~T}$ & 0.241 & $0.069 \pm 0.03$ & $7.2 \times 10^{-3}$ & $\underline{0.026}$ & 0.024 & $0.037 \pm 0.03$ & 0.248 & 0.605 & 0.060 & $0.085 \pm 0.04$ & $\underline{0.025}$ & $\underline{0.027}$ & 0.254 \\
\hline rs $3734007^{*}$ & $\mathrm{~T}$ & 0.160 & $0.077 \pm 0.03$ & $\underline{0.010}$ & $\underline{4.3 \times 10^{-3}}$ & 30.878 & $0.061 \pm 0.04$ & 0.093 & 0.063 & 0.829 & $0.067 \pm 0.05$ & 0.140 & 0.086 & 0.823 \\
\hline rs2241349 & $\mathrm{C}$ & 0.328 & $0.062 \pm 0.02$ & $8.3 \times 10^{-3}$ & $\underline{0.029}$ & 0.033 & $0.062 \pm 0.03$ & $\underline{0.030}$ & $\underline{0.021}$ & 0.321 & $0.057 \pm 0.04$ & 0.102 & 0.323 & 0.053 \\
\hline rs2303676 & A & 0.246 & $-0.005 \pm 0.03$ & 0.849 & 0.812 & 0.994 & $-0.010 \pm 0.03$ & 0.751 & 0.896 & 0.588 & $-0.002 \pm 0.04$ & 0.946 & 0.838 & 0.810 \\
\hline rs11249661* & $\mathrm{C}$ & 0.175 & $0.081 \pm 0.03$ & $4.9 \times 10^{-3}$ & $\underline{3.1 \times 10^{-3}}$ & 30.459 & $0.059 \pm 0.04$ & 0.092 & 0.069 & 0.717 & $0.073 \pm 0.04$ & 0.091 & 0.071 & 0.763 \\
\hline
\end{tabular}

Statistically significant $(p<0.05)$ are indicated in bold and underline. *Significant SNPs in common BD-RT and BD-TT. Abbreviations: MAF: Minor allele frequency; BD-RT, bone density estimated by T-score at distal radius; BD-TT, bone density estimated by T-score at midshaft tibia; s.e.m.: standard error. 
Table 4. The age-dependent associations with genetic variations of SQSTM1 gene and bone density estimated by T-score, controlling for cohort, age, and sex

\begin{tabular}{|c|c|c|c|c|c|c|c|c|c|c|c|c|}
\hline \multirow[b]{2}{*}{ SNP } & \multicolumn{4}{|c|}{ Total } & \multicolumn{4}{|c|}{ Men } & \multicolumn{4}{|c|}{ Women } \\
\hline & beta \pm s.e.m. & Add $p$ & Dom $p$ & $\operatorname{Rec} p$ & beta \pm s.e.m. & Add $p$ & Dom $p$ & $\operatorname{Rec} p$ & beta \pm s.e.m. & Add $p$ & Dom $p$ & $\operatorname{Rec} p$ \\
\hline \multicolumn{13}{|l|}{ BD-RT } \\
\hline $40 \mathrm{~s}$ & & $n=3651$ & & & & $\mathrm{n}=1887$ & & & & $n=1764$ & & \\
\hline rs513235 & $0.029 \pm 0.03$ & 0.349 & 0.384 & 0.553 & $0.103 \pm 0.04$ & $\underline{0.010}$ & $\underline{0.040}$ & $\underline{0.020}$ & $-0.054 \pm 0.05$ & 0.255 & 0.467 & 0.163 \\
\hline rs3734007 & $0.049 \pm 0.04$ & 0.178 & 0.187 & 0.555 & $0.080 \pm 0.05$ & 0.087 & 0.147 & 0.153 & $0.012 \pm 0.06$ & 0.832 & 0.658 & 0.489 \\
\hline rs2241349 & $0.019 \pm 0.03$ & 0.497 & 0.691 & 0.415 & $0.028 \pm 0.04$ & 0.443 & 0.349 & 0.879 & $0.012 \pm 0.04$ & 0.793 & 0.756 & 0.272 \\
\hline rs2303676 & $-0.017 \pm 0.03$ & 0.585 & 0.684 & 0.582 & $-0.048 \pm 0.04$ & 0.246 & 0.899 & $5.4 \times 10^{-3}$ & $0.008 \pm 0.05$ & 0.865 & 0.566 & 0.113 \\
\hline rs11249661 & $0.043 \pm 0.04$ & 0.224 & 0.318 & 0.274 & $0.078 \pm 0.05$ & 0.088 & 0.139 & 0.189 & $0.004 \pm 0.05$ & 0.946 & 0.997 & 0.813 \\
\hline $50 \mathrm{~s}$ & & $\mathrm{n}=1800$ & & & & $n=910$ & & & & $n=890$ & & \\
\hline rs513235 & $-0.040 \pm 0.06$ & 0.478 & 0.329 & 0.760 & $-0.083 \pm 0.07$ & 0.249 & 0.253 & 0.621 & $0.013 \pm 0.08$ & 0.874 & 0.924 & 0.524 \\
\hline rs3734007 & $-0.014 \pm 0.06$ & 0.829 & 0.757 & 0.851 & $-0.077 \pm 0.08$ & 0.333 & 0.234 & 0.836 & $0.071 \pm 0.10$ & 0.477 & 0.402 & 0.887 \\
\hline rs2241349 & $0.017 \pm 0.05$ & 0.724 & 0.832 & 0.675 & $0.039 \pm 0.06$ & 0.539 & 0.483 & 0.842 & $0.007 \pm 0.08$ & 0.929 & 0.898 & 0.675 \\
\hline rs2303676 & $0.045 \pm 0.05$ & 0.388 & 0.324 & 0.856 & $0.068 \pm 0.07$ & 0.324 & 0.290 & 0.748 & $0.031 \pm 0.08$ & 0.692 & 0.584 & 0.928 \\
\hline rs11249661 & $-0.019 \pm 0.06$ & 0.762 & 0.498 & 0.339 & $-0.040 \pm 0.08$ & 0.611 & 0.417 & 0.527 & $0.018 \pm 0.10$ & 0.851 & 0.948 & 0.663 \\
\hline $60 \mathrm{~s}$ & & $n=1698$ & & & & $\mathrm{n}=805$ & & & & $n=893$ & & \\
\hline rs513235 & $0.103 \pm 0.05$ & 0.060 & 0.210 & 0.026 & $0.196 \pm 0.07$ & $8.7 \times 10^{-3}$ & 0.150 & $2.3 \times 10^{-4}$ & $0.012 \pm 0.08$ & 0.882 & 0.688 & 0.612 \\
\hline rs3734007 & $0.022 \pm 0.06$ & 0.724 & 0.861 & 0.110 & $0.134 \pm 0.08$ & $\overline{0.110}$ & 0.395 & $8.9 \times 10^{-3}$ & $-0.096 \pm 0.09$ & 0.297 & 0.301 & 0.666 \\
\hline rs2241349 & $0.022 \pm 0.05$ & 0.654 & 0.911 & 0.439 & $0.052 \pm 0.07$ & 0.440 & 0.700 & 0.313 & $-0.007 \pm 0.07$ & 0.924 & 0.848 & 0.907 \\
\hline rs2303676 & $-0.001 \pm 0.05$ & 0.982 & 0.731 & 0.454 & $-0.030 \pm 0.07$ & 0.688 & 0.682 & 0.850 & $0.025 \pm 0.08$ & 0.742 & 0.418 & 0.400 \\
\hline rs11249661 & $0.028 \pm 0.06$ & 0.641 & 0.932 & 0.100 & $0.145 \pm 0.08$ & 0.075 & 0.358 & $\underline{4.0 \times 10^{-3}}$ & $-0.096 \pm 0.09$ & 0.283 & 0.331 & 0.475 \\
\hline \multicolumn{13}{|l|}{ BD-TT } \\
\hline $40 \mathrm{~s}$ & & $n=3644$ & & & & $\mathrm{n}=1887$ & & & & $n=1757$ & & \\
\hline rs513235 & $0.024 \pm 0.03$ & 0.463 & 0.441 & 0.774 & $0.035 \pm 0.04$ & 0.398 & 0.720 & 0.163 & $0.007 \pm 0.05$ & 0.894 & 0.509 & 0.310 \\
\hline rs3734007 & $0.056 \pm 0.04$ & 0.150 & 0.082 & 0.729 & $0.115 \pm 0.05$ & $\underline{0.019}$ & $\underline{0.011}$ & 0.659 & $-0.016 \pm 0.06$ & 0.793 & 0.972 & 0.276 \\
\hline rs2241349 & $0.055 \pm 0.03$ & 0.070 & $\underline{0.031}$ & 0.690 & $0.106 \pm 0.04$ & $5.7 \times 10^{-3}$ & $1.7 \times 10^{-3}$ & 0.357 & $0.004 \pm 0.05$ & 0.934 & 0.889 & 0.957 \\
\hline rs2303676 & $-0.001 \pm 0.03$ & 0.971 & 0.901 & 0.868 & $-0.050 \pm 0.04$ & 0.244 & 0.495 & 0.113 & $0.031 \pm 0.05$ & 0.530 & 0.951 & 0.146 \\
\hline rs11249661 & $0.054 \pm 0.04$ & 0.152 & 0.108 & 0.928 & $0.105 \pm 0.05$ & 0.027 & $\underline{0.026}$ & 0.396 & $-0.005 \pm 0.06$ & 0.938 & 0.866 & 0.446 \\
\hline $50 \mathrm{~s}$ & & $n=1801$ & & & & $n=913$ & & & & $\mathrm{n}=888$ & & \\
\hline rs513235 & $0.063 \pm 0.05$ & 0.238 & 0.537 & 0.067 & $0.052 \pm 0.07$ & 0.435 & 0.438 & 0.742 & $0.083 \pm 0.08$ & 0.305 & 0.681 & 0.064 \\
\hline rs3734007 & $0.044 \pm 0.06$ & 0.465 & 0.422 & 0.942 & $-0.037 \pm 0.07$ & 0.614 & 0.757 & 0.454 & $0.144 \pm 0.10$ & 0.140 & 0.123 & 0.739 \\
\hline rs2241349 & $0.042 \pm 0.05$ & 0.359 & 0.675 & 0.191 & $-0.011 \pm 0.06$ & 0.848 & 0.573 & 0.629 & $0.099 \pm 0.07$ & 0.177 & 0.255 & 0.287 \\
\hline rs2303676 & $0.005 \pm 0.05$ & 0.915 & 0.939 & 0.676 & $0.035 \pm 0.06$ & 0.571 & 0.970 & 0.128 & $0.001 \pm 0.07$ & 0.991 & 0.764 & 0.582 \\
\hline rs11249661 & $0.057 \pm 0.06$ & 0.335 & 0.299 & 0.869 & $-0.009 \pm 0.07$ & 0.894 & 0.958 & 0.569 & $0.141 \pm 0.09$ & 0.130 & 0.107 & 0.772 \\
\hline $60 \mathrm{~s}$ & & $\mathrm{n}=1738$ & & & & $n=813$ & & & & $\mathrm{n}=925$ & & \\
\hline rs513235 & $0.151 \pm 0.05$ & $\underline{4.7 \times 10^{-3}}$ & $\underline{0.019}$ & $\underline{0.019}$ & $0.034 \pm 0.07$ & 0.628 & 0.905 & 0.144 & $0.252 \pm 0.08$ & $1.2 \times 10^{-3}$ & $\underline{1.8 \times 10^{-3}}$ & 0.080 \\
\hline rs3734007 & $0.125 \pm 0.06$ & $\underline{0.041}$ & 0.038 & 0.426 & $0.053 \pm 0.08$ & 0.509 & 0.569 & 0.605 & $0.167 \pm 0.09$ & 0.062 & 0.057 & 0.517 \\
\hline rs2241349 & $0.095 \pm 0.05$ & 0.054 & 0.209 & $\underline{0.036}$ & $0.043 \pm 0.06$ & 0.501 & 0.429 & 0.845 & $0.132 \pm 0.07$ & 0.069 & 0.449 & $\underline{6.5 \times 10^{-3}}$ \\
\hline rs2303676 & $-0.029 \pm 0.05$ & 0.586 & 0.877 & 0.295 & $0.029 \pm 0.07$ & 0.677 & 0.476 & 0.718 & $-0.075 \pm 0.08$ & 0.326 & 0.466 & 0.322 \\
\hline rs11249661 & $0.118 \pm 0.06$ & $\underline{0.046}$ & 0.055 & 0.292 & $0.040 \pm 0.08$ & 0.609 & 0.577 & 0.905 & $0.173 \pm 0.09$ & 0.049 & 0.074 & 0.195 \\
\hline
\end{tabular}

Statistically significant $(p<0.05)$ are indicated in bold and underline. Abbreviations: BD-RT, bone density estimated by T-score at distal radius; $\mathrm{BD}-\mathrm{TT}$, bone density estimated by $\mathrm{T}$-score at midshaft tibia; s.e.m.: standard error.

$=0.252$, additive $p=1.2 \times 10^{-3}$, dominant $p=1.8 \times 10^{-3}$ ) (Table 4).

\section{Discussion}

In this study, we had investigated the genetic variation of SQSTM1 with bone density using total 7225 subjects (men: 3622, women: 3603) in the KARE study (Table 1). As a result, we investigated 5 SNPs with bone density (Table 3, 4).

The association study showed that the 3 SNPs were significant for the BD-RT, and 4 SNPs were significant for the 
BD-TT. The 3 SNPs (rs513235, rs3734007, and rs11249661) were found to be significant in both BD-RT and BD-TT (Table 3). Moreover, the all significant SNPs had negative beta values, and those means that the carrier of minor allele had strength bone density, and also resistance for osteoporosis. The SNPs of SQSTM1 were also shown age-dependent characteristic association with bone densities (Table 4). And the 3 SNPs (rs513235, rs3734007, and rs11249661) had all negative beta values in significant age-divided subjects, therefore these 3 SNPs would be contribute strength of bone density, and slow the pathogenesis of osteoporosis.

Limitations of this study included the lack of detailed covered SNPs in the SQSTM1 gene, but this report has the value of association study for SQSTM1 and bone density. And, this study present that SQSTM1 gene is clinically relevant to not only Paget's disease but also bone density. But in the near future, it is necessary to verify the relation of SQSTM1 function for bone density or osteoporosis biologically.

In some PDB families exhibiting autosomal dominant inheritance, as well as some sporadic cases, domain-specific mutations in SQSTM1/p62, the gene encoding sequestosome-1, have been identified [6,8]. Laurin et al. found a Proline-Leucine mutation affecting codon 392 (P392L) in the ubiquitin-associated (UBA) domain of the SQSTM1 protein an important cause of PDB in French Canadians [8]. The SQSTM1 gene encodes p62 which is a scaffold protein that plays an important role in regulating $\mathrm{NFkB}$ signaling downstream of the IL-1 receptor, TNF receptor, RANK receptor and nerve growth factor receptor [9]. Mutation screening of families previously reported to have linkage to the PDB2 region [2] and the PDB7 region [5] has shown that most affected subjects carried mutations in the SQSTM1 gene. Studies in mice with targeted inactivation of SQSTM1 have shown impaired osteoclastogenesis in response to PTHrP injection in vivo, indicating that p62 play a role in regulating osteoclast function and activity in response to bone resorbing stimuli [4].

PDB shows a strong age-dependency; it is rarely diagnosed below the age of 50 but becomes progressively more common thereafter, to affect about $8 \%$ of men and $5 \%$ of women in the UK by the age of 80 [12].

It may be possible that mutations or polymorphisms of SQSTM1 interfere with their ability to chaperone other signaling proteins to the proteasome, leading to activation of signaling and possibly contribute to the formation of nuclear inclusions which might be composed of protein aggregates that may cause osteoclast specific gene expression.

In summary, we investigated the presence of bone density-associated SNPs in SQSTM1 gene. And, we found statistically significant SNPs that are associated with bone density traits. Therefore, this study suggests SQSTM1 gene could be related to pathogenesis of osteoporosis.

\section{Acknowledgements}

The Consortium for Large Scale Genome Wide Association Study was supported by genotyping data (Genome Wide association analysis of community based cohort study; 2007) from the Korean Genome Analysis Project (4845-301) from the Korea National Institute of Health (Korea Center for Disease Control, Ministry for Health, Welfare and Family Affairs), Republic of Korea. This study was supported by Korea Nazarene University Research Grants in 2010 .

\section{References}

1. Cho, Y. S., M. J. Go, Y. J. Kim, J. Y. Heo, J. H. Oh, H. J. Ban, D. Yoon, M. H. Lee, D. J. Kim, M. Park, S. H. Cha, J. W. Kim, B. G. Han, H. Min, Y. Ahn, M. S. Park, H. R. Han, H. Y. Jang, E. Y. Cho, J. E. Lee, N. H. Cho, C. Shin, T. Park, J. W. Park, J. K. Lee, L. Cardon, G. Clarke, M. I. McCarthy, J. Y. Lee, B. Oh, and H. L. Kim. 2009. A large-scale genome-wide association study of Asian populations uncovers genetic factors influencing eight quantitative traits. Nat. Genet. 41, 527-534.

2. Cody, J. D., F. R. Singer, G. D. Roodman, B. Otterund, T. B. Lewis, and M. Leppert. 1997. Genetic linkage of Paget disease of the bone to chromosome 18q. Am J. Hum Genet. 61, 1117-1122.

3. Cole, R. E. 2008. Improving clinical decisions for women at risk of osteoporosis: dual-femur bone mineral density testing. J. Am Osteopath Assoc. 108, 289-295.

4. Duran, A., M. Serrano, M. Leitges, J. M. Flores, S. Picard, and J. P. Brown. 2004. The atypical PKC-interacting proein p62 is an important mediator of RANK-activated osteoclastogenesis. Dev. Cell 6, 303-309.

5. Good, D. A., F. Busfield, B. H. Fletcher, P. K. Loveloc, D. L. Duffy, and J. B. Kesting. 2004. Identification of SQSTM1 mutations in familial Paget's disease in Australian pedigrees. Bone 35, 277-282.

6. Hocking, L. J., G. J. Lucas, A. Daroszewska, J. Mangion, M. Olavesen, T. Cundy, G. C. Nicholson, L. Ward, S. T. Bennett, W. Wuyts, W. Van Hul, and S. H. Ralston. 2002. Domain-specific mutations in sequestosome 1 (SQSTM1) cause familial and sporadic Paget's disease. Hum Mol. Genet. 11, 2735-2739. 
7. Joung, I., J. L. Strominger, and J. Shin. 1996. Molecular cloning of a phosphotyrosine-independent ligand of the p56lck SH2 domain. Proc. Natl. Acad Sci. USA 93, 5991-5995.

8. Laurin, N., J. P. Brown, J. Morissette, and V. Raymond. 2002. Recurrent mutation of the gene encoding sequestosome 1 (SQSTM1/p62) in Paget disease of bone. Am J. Hum Genet. 70, 1582-1588.

9. Moscat, J. and M. T. Diaz-Meco. 2002. The atypical PKC scaffold protein P62 is a novel target for anti-inflammatory and anti-cancer therapies. Adv. Enzyme Regul. 42, 173-179.

10. Rabbee, N. and T. P. Speed. 2006. A genotype calling algorithm for affymetrix SNP arrays. Bioinformatics 22, 7-12.
11. Ralston, S. H. 2008. Pathogenesis of Paget's disease of bone. Bone 43, 819-825.

12. van Staa, T. P., P. Selby, H. G. Leufkens, K. Lyles, J. M. Sprafka, and C. Cooper. 2002. Incidence and natural history of Paget's disease of bone in England and Wales. J. Bone Miner Res. 17, 465-471.

13. Wooten, M. W., M. L. Seibenhener, V. Mamidipudi, M. T. Diaz-Meco, P. A. Barker, and J. Moscat. 2001. The atypical protein kinase C-interacting protein p62 is a scaffold for NF-kappaB activation by nerve growth factor. J. Biol. Chem 276, 7709-7712

초록 : 한국인에서 골밀도와 SQSTM1 유전자 변이의 연관성

진현석·엄용빈 ${ }^{1} \star$

(아주대학교 의과대학 의학유전학과, ${ }^{1}$ 나사렛대학교 임상병리학과)

골다공증은 복합적 전신 골격 질환으로, 공중 보건 분야의 전세계적인 주요한 관심 질환의 한 가지이다. 골다 공증은 유전적 영향을 받는 질환으로, 낮은 골밀도와 적은 외력 의한 골다공성 골절 등의 특징을 보이며, 강한 유전성을 나타내는 질환이다. 그러나, 낮은 골밀도과 연관된 특정한 유전자의 다형성은 아직까지 많이 알려져 있지 않다. 본 연구에서는 SQSTM1 유전자의 유전적 다형성과 낮은 골밀도 사이의 상관성을 확인하기 위해, 한국 인 유전체 연구(Korean Association Resource, KARE)에서 골밀도를 측정한 7,225명(남성: 3,622명, 여성: 3,603명) 을 대상으로 SQSTM1 유전자 다형성과 골밀도 간의 선형 회기 분석을 하였다. BD-RT (원위 요골의 T 점수로 예측한 골밀도)에서 SQSTM1 유전자에서 3개의 SNP (rs513235, rs3734007, rs11249661)가 유의한 상관성이 있는 것으로 나타났으며, BD-TT (중위 경골의 T 점수로 예측한 골밀도)에서는 4 개의 SNP (rs513235, rs3734007, $\mathrm{rs} 2241349, \mathrm{rs} 11249661)$ 가 유의한 상관성이 있는 것으로 나타났다. 특히 3개의 SNP (rs513235, rs3734007, rs11249661)는 BD-RT와 BD-TT 두 종류의 골밀도에서 공통적으로 유의한 상관성을 보였다. 이러한 결과로 미루 어 골밀도와 SQSTM1 유전자의 다형성 간에 통계적으로 유의한 상관성을 가지며, SQSTM1 유전자는 골다공증의 발병과정에 관련이 있을 것으로 사료된다. 